\title{
Digital Technologies, Music Therapy and Inclusion
}

\author{
Andreia Amaral \\ Escola Superior de Educação de \\ Castelo Branco \\ Castelo Branco, Portugual \\ andreia.antunes.amaral@gmail.com
}

\author{
Henrique Gil \\ Age.Comm - Instituto Politécnico \\ de Castelo Branco \\ Castelo Branco, Portugal \\ hteixeiragil@ipcb.pt
}

\author{
Dalila Daniel \\ Escola Superior de \\ Educaçãode Castelo Branco \\ Covilhã, Portugal, \\ dalilaesteves@sapo.pt
}

\author{
Rita Moreira \\ Escola Superior de \\ Educaçãode Castelo Branco \\ Castelo Branco, Portugal \\ ritadiana@gmail.com
}

\author{
Zélia Duarte \\ Escola Superior de Educação \\ de Castelo Branco \\ Castelo Branco, Portugal \\ zeliasofiaduarte@gmail.com
}

\begin{abstract}
Abstrat - The current school is searching for, more than ever, to contribute to the inclusion of children and young people with $D I D$, in conditions that are not always the best, if we consider the different difficulties experienced every day. The Digital Technologies, in association with Music and the concept of Music Therapy, can make a strong contribution in the reduction of these difficulties, using available software. In this article we propose to present, by way of example, Youtube importance its potential as an intervention tool, through Music, with individuals with Intellectual and Developmental Difficulty.
\end{abstract}

Keywords - Intellectual and Developmental Difficulty, Inclusion, Music Therapy, Digital Technologies, Youtube.

\section{INTRODUCTION}

The search for new approaches to the promotion of inclusion in diversified contexts is still a goal to be achieved within the Portuguese education system. International and national legislation around this issue has helped to define innovative strategies, with clear but not always easy to achieve goals. Information and Communication Technologies have provided a more promising world view, from the outset, in accessing a huge amount of content and resources available to all of us, namely in an educational context. It is at school that eventually the effect of this change has been most felt, also among students with Intellectual and Developmental Disabilities. Music has been asserting itself as a resource in connection with other pedagogical and educational action tools, allowing the establishment of contact points to enhance other approaches. In this sense, we will portray its importance in the connection with the Information and Communication Technologies, highlighting the therapeutic aspect that it sometimes has, in the so-called concept of Music Therapy, in the offspring of education and inclusion.

\section{INTELLECTUAL DEVELOPMENTAL DIFFICULTY AND INCLUSION}

Schools do not always have the means to prove themselves sufficiently to be included. All young people thus have the right to participate in a general educational model that respects their differences and specificities. In accordance with the Practice Support Handbook - Towards Inclusive
Education (2018) [3], which supports the existing Decree Law 54/2018, the school should provide the student with all the support that enables sustained decision making. and informed about the options to follow in their school life, based on their personal expectations of building a life project in society, with adequate professional, social and family insertion.

When the student expresses difficulty in autonomously identifying the difficulties and potentialities for the realization of personal and professional goals, clearly and objectively, it is important to make him / her know different possibilities. Performing activities that enable on-site knowledge often arouses interest in a new area.

Although integration and inclusion promote child insertion, what differentiates them is that while integration is partial insertion, inclusion is total and conditioned insertion. In integration, insertion depends largely on the student's greater or lesser ability to adapt to the school. In inclusion, insertion focuses on the particularities of each student. Inclusion must also include articulation and participation among parents, local authorities, the community, teachers and school management, and the philosophy of heterogeneity must be adopted to extend educational opportunities to all students. In this sense, with the implementation of DecreeLaw no. 54/2018 of July 6 , which bets on an inclusive school where each and every student, regardless of their personal and social situation, finds answers that enable them to acquire a education and training facilitating their full social inclusion. This political priority realizes the right of every student to an inclusive education that responds to their potential, expectations and needs within the framework of a common and plural educational project that provides everyone with participation and a sense of belonging in an effective level of equity, contributing thus decisively for higher levels of social cohesion. The Salamanca Declaration in 1994 set out the principles, policies and practices in the area of special educational needs, especially with regard to the inclusion of children, youth and adults with special educational needs within the regular education system. With Decree Law 3/2008 of 7 January, the objective was to create conditions for adapting the teaching and learning process to the needs of students with limitations in terms of activity and 
participation. He said that children with Special Educational Needs, and their limitations, result from changes at the functional and structural level, being permanent and affecting the student's skills in communication, learning, mobility, autonomy, interpersonal and social relationships. of social participation. However, despite the legislative effort, it has not been at all easy to characterize, in terms of nomenclature, a population that has disparate characteristics with regard to Intellectual and Developmental Difficulties [13]. In this sense, it becomes imperial to forget terminology as "mentally retarded" or even "abnormal". In fact, Portuguese legislation itself was adopting consequences of scientific contributions and this is how it went from a concept of "abnormal" (1915), emphasizing the medical forum, to concepts emphasizing cultural and social handicaps as "physically and psychically diminished". "(1964),“" inadequate "and" disabled "(1973), accompanied by" different "(1975), relocating the cause of the person's disability to the social and its organization [5]. Nowadays, the image that is generated in relation to the concept of Intellectual and Developmental Difficulty, in the paradigm of individual functionality, where the importance of adaptation is complemented by the provision of individualized and personalized support, appropriate to each case (not massified). they are crucial [13]. Therefore, medical diagnosis should not be made solely on the basis of intellectual factors, but also include social and practical factors; In other words, the focus should be on the quality of interaction between the subject (with DID) and their ecological context. Continuing, Intellectual and Developmental Difficulty can thus be characterized by visible limitations in intellectual functioning, two belowaverage standard deviations, accompanied by limitations in adaptive skills, manifested in the conceptual, social and practical domains, and their onset be older than 18 years [7]. In turn, this concept can not only be considered as an individual characteristic, in which the potentialities and limitations are visible, also resulting from the interaction of the subject with the environment where it is inserted. In addition, the assessment should be carried out taking into account cultural and linguistic differences as well as sensory, motor, adaptive and communicative aspects. In other words, they should not be excluded from all the subject's experiences.

\section{DIGITAL TECHNOLOGIES, MUSIC THERAPY AND YOUTUBE}

With regard to digital technologies in a society in constant social and cultural change, Information and Communication Technologies have contributed to the construction of a new type of society that leads different ways of knowing, such as knowing how to look, how to interpret, how to know. learning and knowing how to integrate diverse sources, which leads to the need for children to acquire habits of research, analysis and selection of information and skills that allow them access to knowledge and active participation in social life [4]. Awareness of the urgent need for schools to open themselves to the world of so-called technologies has been gaining shape, materializing in various measures. In Portugal and according to [12], the first measure to introduce new technologies in education took place with the emergence of the MINERVA Project, between 1985 and 1994 and had a huge impact on a number of schools, namely in the 1st
Cycle. Basic Education, because "(...) had as its objectives: i) the computer equipping of schools, the training of teachers and teacher trainers; ii) the development of educational software; iii) the promotion of research in the area of ICT use in primary and secondary education ". However, as it was developed in only a few schools, it fell short of expectations. Currently, and following other innovative initiatives, the Education Technology Plan (PTE) has been implemented, which allows: 'Improvement of students' teaching and achievement; Equal opportunities in access to technological equipment; The modernization of schools, enabling schools to network and teachers to work collaboratively" [11].

By adapting ICT to learning disabilities, according to [14], children with SEN progress in their cognitive development if they are stimulated to interact with people and objects and are then able to develop their own knowledge through discovery and learning. creating new relationships between real-world facts. Currently, one of the greatest challenges for teachers is to find out how to monetize ICT in order to enhance the intellectual, affective and social development of students with IDD. ICTs should enhance the experiences of students with IDD in order to integrate them into a changing society. Before choosing the software, one should check the subject's needs and evaluate his preferences for another presentation system for communication, and then choose the software. ICT is arguably a necessity today, as it is an added value in education, according to Quelhas (2011, p. 14) [10] “(...) a developing phenomenon that promotes a new paradigm of society in which makes it possible for people with disabilities to be integrated into working life (...) ". Thus, rather than providing assistance to the subject's needs, ICTs have the role of assisting in the development of cognitive, creative and human potential. In this sense, Music assumes a 'therapeutic' aspect that has long been recognized, and may play a very important role in establishing bridges between the role available today, with individuals with IDD.

Regarding the concept of music therapy, from a brief historical perspective, it should be noted that sound has long accompanied man in his journey through history. The use of music as a therapeutic agent is not new. For [1] music is a universal language, which has been part of human history since the earliest civilizations. According to anthropological data, the first songs would be used in rituals such as birth, marriage, death, disease recovery and fertility. Pythagoras, referred to by Brescia in 2003, has shown that the correct sequence of sounds when played on an instrument can alter behavioral patterns and develop a healing process. There are currently several definitions for music. The purpose was the restoration and rehabilitation of physical, mental or emotional problems. Music, throughout the ages has been pointed as a complementary therapeutic resource that comprehends several dimensions of the individual. The psychological and mental dimension, which reinforces identity, self-concept, promoting verbal expression and favoring fantasy. The social dimension, which promotes group participation through entertainment and discussion. And the spiritual dimension, which facilitates spiritual expression and comfort, the expression of doubt, anger and fear. Music, as a therapeutic instrument in education, allows the development of sensitivity, creativity, rhythmic sense, imagination, memory, concentration, self-discipline, respect for others, socialization and affection, also contributing to an effective body and movement awareness [1]. 
Given that there are individuals with disabilities or physical, mental or social integration problems, the importance and power of music in the integral development of man should be emphasized. In these cases, the function of music is expanded to give way to its therapeutic character. It has unmatched power over body and mind and is sometimes used as a method of relaxation. Music therapy, as rhythm, melody and harmony work, has the capacity to establish relations of concentration and order. According to Wigram (2000), cited by [8] music therapy aims at physical and psychological stimulation, perceptive awareness, emotional expression, communicative and cognitive ability, social behavior and individual capacities. These objectives are patented in the fundamental orientations of music therapy: behavioral, psychodynamic and humanistic orientation.

With regard to the exploratory part of the case, in order to try to include and motivate students with learning disabilities, we proposed, to a class of Education and Training Course (CEF), equivalent to the ninth grade of education and professional output of Support for Education. Childhood. It is a sample consisting of twenty four students, fourteen female and ten male. Ages range from fifteen to eighteen. Of the group, two students are covered by universal measures under this Decree Law, and in legal terms are corroborated by the psychologist and the special education teacher. One of the students is diagnosed with ADHD, regularly attending developmental consultations and a case of dyslexia. Apart from these two specific cases, there are difficulties in concentration, the self-esteem of most students is lacking and there are not always easy interpersonal relationships. Also to mention that three students are institutionalized.

We started this study with the following starting question: what is the contribution of music therapy in the educational process of these students? Our intention was to use music therapy based on the following objectives: stimulate concentration, integrate students through a common project and raise awareness of a classical music culture adapted to their daily realities and the production of a piece of music. Regarding the methodology, we opted for a qualitative approach, favoring a focus group approach, followed by video recording as a result of the intervention. This "project" lasted four weeks.

Regarding digital resources, we used Traductor software, as a translation tool, Youtube and Karaoke, in relation to music. Software related to music, combining both image and melody, allows a real interaction with the subjects, allowing the auditory recreation of a piece. In turn, with Tradcutor, students once again stimulate writing skills and being an interactive tool also allows them to develop writing.

In the first phase, we first heard a musical piece entitled: Va Pensiero, by Verdi. Momentarily, there was a clear reluctance, as it was an area sung in the nineteenth-century Italian language. The students viewed, through Youtube, the area. Promptly, at the first hearing / visualization, discomfort and denial suggest during the first bars. In a second phase, it was our intention to translate the complexity of the piece. In this way, the text was contextualized, alluding to the contemporary issue of refugees in the present world. In this context, competences associated with citizenship, knowing how to listen and relate were developed as the text was translated orally. In a second instance, the software was resorted to: Traductor. The students started by entering the text so that the translation was automatic. However, afterwards, it was revised. Having made the discovery of the source text, the challenge was made to elaborate a second text, adapted to the school reality, whose metric and rhythm fit the original music. Digital translation stimulated writing. It was good to be able to observe the whole involvement of the class in matters of interpretation, semantic stimulation and even a taste for writing. Four academic times were devoted to this task, because it was not easy to adapt a letter to the original metric and, in turn, to describe the reality that the class wanted: the school experience. In a third phase, he tried to stimulate his hearing once again. The students were writing the new letter. At this stage, the discomfort described in the first stage was no longer present. Instead, a climate of musical discovery arose. It was recurrent to hear from other teachers that the students asked to hear, as ambient sound, the play. Another phase, with the use of Youtube software, the class can interpret the song with the adapted lyrics. It was gratifying, even though the detuning problems weren't easy to control. The posture was improved as well as the concentration as they had to be attentive to the musical interpretation. In the last phase, they interpreted the music through the Karaoke software. The result was positive, as well as the moments of reflection that followed. The final production resulted in a collaborative work in order to control emotions, postures and even behaviors, promoting self-confidence.

With this article we set out to draw attention to a theme that, for us, still lacks all possible contributions, such as the need to implement truly inclusive practices. Citizens' accessibility to Digital Technologies is crucial for the development of a more impartial society, even more so when we contextualize this yearning, in school, as an institution, or in other contexts today. Music, by its very nature and characteristics of such a peculiar and transversal form of artistic expression, is today an asset in the approaches we have proposed here, contributing strongly to the creation of well-being and happiness among all. who experience it. It is an effective tool, namely, in promoting effective processes to combat exclusion, abandonment, and building bridges with other approaches and strategies that are also proven effective, such as those that embody the use of Digital Technologies for inclusion.

\section{REFERENCES}

[1] Brescia, V. P. Educação Musical: Bases psicológicas e ação preventiva. Campinas: Unioversidade de Campinas, 2003.

[2] Correia, L. Alunos com Necessidades Educativas Especiais nas Classes Regulares. Porto: Porto Editora, 1999.

[3] Decreto Lei n. ${ }^{\circ} 54 / 2018,6$ de julho, Diário da Républica, n. ${ }^{\circ}$ 129/2018, Série I de 6 de julho de 2018, pp. 2018.

[4] Duarte, J., Marques, T., Tomás, A., and Pereira, M. As TIC nos primeiros anos de escolaridade. In J. P. Ponte, A Formação para a Integração das TIC na Educação Préescolar e no $1^{\circ}$ Ciclo do Ensino Básico. Porto: Porto Editora, 2002, pp. 40-48

[5] Ferreira, M. A Construção da Escola Inclusiva: Um Estudo Sobre a Escola de Bragança. Edição do Instituto Politécnico de Bragança, 2003.

[6] Fortunas, M. O Desenvolvimento Musical em crianças com Paralisia Cerebral. Relatório de Atividade Profissional. Braga: Universidade Católica, 2015.

[7] Gonçalves, P. Comportamento Adaptativo e os Apoios. Dissertação de Mestrado em Reabilitação Psicomotora. Faculdade de Motricidade Humana da Universidade de Lisboa, 2014. 
[8] Lobo, A. o papel da musicoterapia no processo educativo de crianças com perturbação de hiperatividade com défice de atenção. Dissertação de Mestrado em Ciências da Educação na Especialidade em Educação Especial, Domínio Cognitivo e Motor. Lisboa: Escola Supeior de Educação João de Deus, 2014.

[9] Pedroso, J. Para uma Educação Inclusiva: Manual de Apoio à Prática. Lisboa: Ministério da Educação /Direção Geral da Educação, 2018.

[10] Quelhas, R. O Uso das TIC por jovens com Trissomia 21 do Ensino Básico: Um estudo de caso. Dissertação de Mestrado. Castelo Branco: Escola Superior de Educação de Castelo Branco, Instituto Politécnico de Castelo Branco, 2011.

[11] Ribeiro, J., Almeida, A. M., and Moreira, A. A utilização das TIC na Educação de Alunos com Necessidades Educativas Especiais: resultados da aplicação piloto do inquérito nacional a Coordenadores TIC/PTE. Indagatio Didactica, 2 (1), 2010, pp. 94-124.
[12] Santos, B. Ciberleitura, o contributo das TIC para a leitura no 1CEB (Tese de mestrado não publicada). Lisboa: Faculdade de Ciências Sociais e Humanas, Universidade Nova de Lisboa, 2005

[13] Santos, S. and Morato, P. Acertando o Passo! Falar de Deficiência Mental é um erro: deve falar-se de Dificuldade Intelectual e Desenvolvimental (DID). Por quê?. Rev. Brasil. Ed. Esp., Marília, v. 18., 2012, pp. 64-79.

[14] Silva, A. Ensinar e Aprender com as Tecnologias - Um estudo sobre as atitudes, formação, condições de equipamento e utilização nas escolas do $1^{\circ}$ Ciclo do Ensino Básico do Concelho de Cabeceiras de Basto. Dissertação de Mestrado. Braga: Universidade do Minho, 2004. 